\title{
EFEKTIVITAS MODEL PEMBELAJARAN TREFFINGER TERHADAP HASIL BELAJAR DAN KEMAMPUAN BERPIKIR KREATIF SISWA PADA MATERI EKOLOGI
}

\author{
Putri Grasella Simangunsong ${ }^{1 *}$, Adriana Y. D Lbn. Gaol ${ }^{2}$, M. Sahnan ${ }^{3}$ \\ ${ }^{1,2}$ Program Studi Pendidikan Biologi, FMIPA, Universitas Negeri Medan, Jl. Willem Iskandar Psr. V, Medan Estate, Medan, \\ Indonesia, 20221 \\ ${ }^{3}$ SMA Swasta Dharma Pancasila Medan, Jalan Dr. Mansyur No. 71 C, Medan, Indonesia, 20225 \\ ${ }^{*}$ E-mail : putrigrasellasimangunsong@gmail.com
}

\begin{abstract}
ABSTRAK
Penelitian ini bertujuan untuk mengetahui efektivitas model pembelajaran Treffinger terhadap hasil belajar dan kemampuan berpikir kreatif siswa pada materi ekologi. Jenis penelitian ini adalah pra-eksperimen, dimana populasi dari penelitian ini adalah seluruh siswa kelas X MIA SMA yang berjumlah 124 orang. Teknik pengambilan sampel yang dilakukan adalah random sampling dimana sampelnya adalah kelas $X$ MIA $X$ berjumlah 34 orang. Hasil penelitian menunjukkan bahwa tingkat penguasaan siswa mencapai 80,47 termasuk kategori tinggi, ketuntasan belajar siswa mencapai 91,18 \% termasuk kategori tuntas, ketercapaian indikator mencapai $100 \%$ termasuk kategori tercapai, dan kemampuan berpikir kreatif siswa yang mencapai $75,04 \%$ termasuk ke dalam kategori kreatif. Sehingga dapat disimpulkan bahwa model pembelajaran Treffinger efektif digunakan pada materi ekologi.
\end{abstract}

Kata Kunci: Hasil Belajar, Kemampuan Berpikir Kreatif, Model Pembelajaran Treffinger

\section{ABSTRAK}

This study aims to determine the effectiveness of Treffinger's learning model on learning outcomes and students' creative thinking ability in an ecological material. This type of research is pre-experiment, where the population of this study is all students of class X MIA High School totaling 124 people. The sampling technique used was random sampling where the sample was class X MIA X totaling 34 people. The results showed that the level of mastery of students reached 80.47 including high categories, student learning completeness reached $91.18 \%$ including the complete category, the achievement of indicators reached $100 \%$ including the achieved category and students' creative thinking ability which reached $75.04 \%$ included in a creative category. So it can be concluded that Treffinger's learning model is effective for ecological material.

Keywords: Creative Thinking Ability, Learning Outcomes, Treffinger Learning Models

\section{PENDAHULUAN}

Pendidikan

merupakan

sarana

mengembangkan potensi peserta didik dan mampu merubah tingkah laku peserta didik ke arah yang lebih baik. Hal ini tercantum dalam Undang-Undang No. 20 Tahun 2003 tentang Sistem Pendidikan Nasional menyatakan bahwa pendidikan adalah usaha sadar dan terencana untuk mewujudkan suasana belajar dan proses pembelajaran agar peserta didik secara aktif mengembangkan potensi dirinya untuk memiliki kekuatan spritual keagamaan, pengendalian diri, kepribadian, kecerdasan, akhlak mulia, serta keterampilan yang diperlukan dirinya, masyarakat, bangsa dan negara.

Hal yang paling utama di dalam keseluruhan proses pendidikan di sekolah adalah proses belajar mengajar. Ini berarti bahwa keberhasilan pencapaian tujuan pendidikan banyak bergantung kepada bagaimana proses belajar mengajar dapat berlangsung secara efektif. Belajar efektif itu dimulai dari lingkungan belajar yang berpusat pada siswa (Trianto, 2011). Dimana siswa tidak hanya pasif menerima informasi dan pengetahuan apa yang diberikan guru tetapi juga dapat meningkatkan keterampilan berpikir siswa. Sebagaimana dinyatakan oleh Zannah dalam Hasruddin (2018) bahwa keterampilan berpikir peserta didik perlu dikembangkan untuk menghadapi dunia ilmu pengatahuan dan teknologi yang semakin maju, dimana peserta didik harus belajar dan menerapkan pengetahuannya untuk memecahkan masalahmasalah riil.

Kenyataannya di lapangan menunjukkan bahwa dalam proses belajar mengajar masih berorientasi pada guru (teacher centered learning), yaitu guru lebih mendominasi pembelajaran sehingga membuat siswa menjadi pasif. Padahal, proses belajar mengajar dikatakan efektif apabila menerapkan 
pembelajaran siswa aktif (active learning). Dengan demikian, proses pembelajaran ditentukan oleh kemampuan guru dalam menggunakan model pembelajaran dengan tepat. Apabila model yang digunakan sudah semakin tepat, diharapkan semakin efektif pula pencapaian tujuan pembelajaran serta kemampuan guru dalam mengelola proses pengajaran melalui model yang diterapkan.

Salah satu masalah utama dalam pembelajaran pada pendidikan formal (sekolah) adalah masih rendahnya daya serap peserta didik (Trianto, 2011). Oleh karena itu, perlu didukung dengan adanya model pembelajaran yang menekankan pada kemampuan berpikir, khususnya kemampuan berpikir kreatif.

Salah satu materi dari pembelajaran Biologi untuk kelas $X$ adalah materi Ekologi. Pembelajaran Ekologi memiliki konsep yang bersifat abstrak, memerlukan hafalan, pemahaman, terapan dan peristiwa yang sering terjadi dalam kehidupan seharihari. Sehingga keterampilan berpikir kreatif sangat penting untuk direalisasikan guru dalam proses pembelajaran ini, supaya peserta didik mampu menyelesaikan permasalahan di lingkungan terkait materi Ekologi dengan cara-cara yang kreatif dan inovatif. Selain itu juga peserta didik dapat mengasah kemampuan berpikir kreatifnya, guna mempersiapkan diri menjadi generasi yang mampu menemukan solusi dari suatu permasalahan dari berbagai bidang. Setiap guru harus mengetahui cara yang tepat untuk mengembangkan potensi berpikir kreatif siswa dalam proses pembelajaran di kelas, karena setiap siswa memiliki keterampilan berpikir kreatif yang berbedabeda.

Untuk menumbuhkan keaktifan siswa, sebaiknya dalam proses belajar mengajar siswa diberi kesempatan untuk langsung terlibat dalam kegiatankegiatan atau pengalaman-pengalaman ilmiah. Hal ini dapat meningkatkan kemampuan berpikir. Kemampuan berpikir memegang peranan besar dalam peningkatan kualitas individu, karena siswa mempunyai kemampuan psikomotorik mental disamping kemampuan psikomotorik manual. Pembelajaran yang menekankan keaktifan siswa merupakan salah satu upaya yang dapat dilakukan untuk memperbaiki kualitas pembelajaran. Salah satu model yang dapat digunakan dalam pembelajaran Biologi untuk mengembangkan kemampuan berpikir kreatif adalah model Treffinger. Menurut Munandar (2000), Model Treffinger merupakan salah satu dari sedikit model yang menangani kreativitas secara langsung dan memberikan saran-saran praktis bagaimana mencapai keterpaduan. Dengan melibatkan baik keterampilan kognitf maupun afektif pada setiap tingkat dari setiap model ini Treffinger menunjukkan saling hubungan dan ketergantungan antara keduanya dalam mendorong belajar kreatif.

Penelitian yang dilakukan oleh Wirahayu (2017) Penerapan Model Pembelajaran Treffinger dan Keterampilan Berpikir Divergen Mahasiswa membuktikan bahwa penggunaan model pembelajaran Treffinger memberikan pengaruh terhadap kemampuan berpikir divergen mahasiswa. Yunus (2018) juga membuktikan bahwa penerapan model pembelajaran Treffinger dapat meningkatkan hasil belajar siswa kelas VIII ${ }^{1}$ SMP Negeri 6 kota Ternate pada konsep usaha dan energi.

Berdasarkan hasil observasi langsung yang dilakukan di kelas X MIA SMA, hasil observasi menunjukkan bahwa hanya 8 dari 33 siswa yang berani mengajukan pertanyaan di dalam kelas dan mengutarakan pendapatnya tentang keadaan usaha disekitar kehidupan sehari - hari mereka. Sedangkan siswa yang lainnya tergolong pasif karena pada saat proses pembelajaran berlangsung, siswa hanya duduk diam menerima setiap penjelasan atau informasi yang diberikan oleh guru. Dan ketika guru memberikan satu permasalahan terkait dengan materi yang diajarkan, sering sekali beberapa siswa memberikan jawaban yang sama untuk satu permasalahan. Siswa juga dinilai kurang mampu dalam menghubungkan suatu masalah dengan konsep yang telah mereka pelajari sebelumnya. Hal tersebut menunjukkan bahwa keterampilan berpikir kreatif siswa masih perlu ditingkatkan. Hal ini dapat dilihat berdasarkan KKM (Kriteria Ketuntasan Minimal) khususnya untuk mata pelajaran Biologi di kelas X MIA adalah 75. Sementara siswa yang mendapat nilai di bawah KKM ada sekitar $60 \%$ dari 33 jumlah siswa. Berdasarkan uraian di atas, maka penelitian ini bertujuan untuk mengetahui efektivitas model pembelajaran treffinger terhadap hasil belajar dan kemampuan berpikir kreatif siswa pada materi ekologi.

\section{METODE PENELITIAN}

Pengumpulan data maupun informasi yang dibutuhkan dalam penelitian ini dilaksanakan di SMA Swasta Dharma Pancasila Medan. Penelitian dilakukan selama 6 bulan, pada bulan Januari - Juni 2018. Populasi pada penelitian ini adalah seluruh kelas X MIA SMA. Sampel yang digunakan dalam penelitian adalah kelas X MIA X SMA yang berjumlah 34 orang dengan teknik Random Sampling. Instrumen penelitian ini yaitu tes hasil belajar dan lembar observasi kemampuan berpikir kreatif. Jenis penelitian ini adalah penelitian pra-eksperimen, yang bertujuan untuk mengetahui fakta-fakta yang terjadi pada pembelajaran biologi dengan memberikan perlakuan terhadap satu kelompok siswa dengan 
menggunakan model pembelajaran Treffinger pada materi Ekologi. Teknik analisis data dilakukan dengan menghitung tingkat penguasaan siswa, ketuntasan belajar, tingkat ketercapaian indikator, dan kemampuan berpikir kreatif siswa.

\section{HASIL PENELITIAN}

\section{Hasil Belajar Siswa}

Nilai hasil belajar siswa diperoleh dari tes yang dilakukan di awal dan akhir proses pembelajaran dengan menggunakan model pembelajaran Treffinger. Nilai hasil belajar siswa yang berkaitan dengan materi ekologi pada tes awal (Pre Test) dan tes akhir (Post Test) disajikan pada lampiran 15. Nilai rata-rata siswa saat diberi tes awal (Pre Test) sebesar 49,88 dengan simpangan baku (SD) sebesar 7,92. Sedangkan nilai rata-rata siswa saat diberi tes akhir (Post Test) sebesar 80,47 dengan simpangan baku (SD) sebesar 7,15. Dari kedua data tersebut dapat dilihat adanya peningkatan hasil belajar siswa pada pembelajaran yang menggunakan model pembelajaran Treffinger pada materi ekologi. Hal ini karena rata-rata nilai Pre-Test masih tergolong sangat rendah, sedangkan rata-rata nilai Post-Test sudah tergolong tinggi.

\section{Tingkat Penguasaan Siswa}

Dari hasil pengolahan data, terdapat perbedaan antara tingkat penguasaan siswa pada saat pre-test dan post-test. Dimana pada saat pre-test atau sebelum diberikan pengajaran dengan model pembelajaran Treffinger tidak ada siswa yang tergolong kategori sangat tinggi, tinggi dan cukup. Sebanyak 6 siswa $(17,65 \%)$ tergolong dalam kategori tingkat penguasaan rendah, dan sebanyak 28
$(82,35) \%$ siswa tergolong dalam kategori sangat rendah dengan perolehan skor rata-rata tingkat penguasaan siswa saat pre-test sebesar 49,88. Maka dapat disimpulkan bahwa secara umum tingkat penguasaan siswa pada materi ekologi di kelas X MIA $X$ SMA sebelum diberi pengajaran dengan model pembelajaran Treffinger termasuk ke dalam kategori sangat rendah.

Sedangkan nilai post-test diketahui bahwa terdapat 5 siswa $(14,7 \%)$ yang memperoleh tingkat penguasaan dengan kategori sangat tinggi, 18 siswa $(52,94 \%)$ yang memperoleh tingkat penguasaan dengan kategori tinggi, 9 siswa $(26,47 \%)$ yang memperoleh tingkat penguasaan dengan kategori cukup, 2 siswa $(5,89 \%)$ yang memperoleh tingkat penguasaan dengan kategori rendah, dan tidak ada siswa yang memperoleh tingkat penguasaan dengan kategori sangat rendah. Dengan perolehan skor rata - rata tingkat penguasaan siswa pada saat post-test adalah sebesar 80,47 sehingga dapat disimpulkan bahwa secara umum tingkat penguasaan siswa pada materi ekologi di kelas X MIA X SMA setelah diberikan pengajaran dengan menggunakan model pembelajaran Treffinger tergolong kategori tinggi.

\section{Ketuntasan Belajar}

Dalam menganalisis ketuntasan belajar, ada dua hal yang harus diperhatikan yaitu, ketuntasan belajar secara individual dan ketuntasan belajar secara klasikal. Siswa dikatakan tuntas, apabila nilainya $\geq 75$ dan kelas dikatakan tuntas bila $85 \%$ atau lebih dari keseluruhan siswa berhasil tuntas. Persentase tingkat ketuntasan belajar siswa dalam pembelajaran ekologi disajikan dalam Tabel 1.

Tabel 1. Persentase Tingkat Ketuntasan Siswa

\begin{tabular}{ccccc}
\hline No & Nilai Tes & Tingkat Ketuntasan & Jumlah Siswa & Persentase Jlh. Siswa \\
\hline 1 & $<75$ & Tidak Tuntas & 3 & $8,82 \%$ \\
2 & $\geq 75$ & Tuntas & 31 & $91,18 \%$ \\
\hline
\end{tabular}

Berdasarkan tabel diatas, terdapat 3 orang siswa yang belum tuntas belajar dan 31 orang siswa yang sudah tuntas belajar. Dengan demikian ketuntasan klasikal telah termasuk kategori tuntas yaitu $91,18 \%$ dengan pencapaian 31 orang siswa yang telah mencapai nilai tes di atas 75 .

\section{Ketuntasan Pencapaian Indikator}

Ketuntasan pencapaian indikator pada penelitian ini dapat dilihat berdasarkan nilai yang diperoleh untuk setiap butir soal. Indikator dikatakan tercapai apabila memperoleh skor $>75 \%$ atau minimum nilai 75 dari skor maksimal total. Ketuntasan pencapaian indikator berdasarkan nilai yang diperoleh siswa setiap butir soal, disajikan pada Tabel 2. Berdasarkan Tabel 2 dapat dilihat bahwa 5 indikator telah tercapai, sehingga dapat disimpulkan bahwa ketercapaian indikator yang diajukan dalam melaksanakan pembelajaran biologi pada materi ekologi di kelas X MIA X secara keseluruhan tercapai. 
Tabel 2. Ketuntasan Pencapaian Indikator

\begin{tabular}{|c|c|c|c|c|}
\hline No & Indikator & No. Soal & Rata - rata (\%) & Kategori \\
\hline 1 & Menjelaskan konsep ekologi & $1,12,18,21$ & 83,82 & Tercapai \\
\hline 2 & $\begin{array}{l}\text { Mengelompokkan dan menjelaskan komponen } \\
\text { penyusun dan interaksi ekosistem }\end{array}$ & $3,5,7,19,23$ & 82,35 & Tercapai \\
\hline 3 & $\begin{array}{l}\text { Menghubungkan pengertian aliran- aliran energi } \\
\text { melalui rantai makanan, jaring-jaring makanan } \\
\text { dan piramida makanan. }\end{array}$ & $\begin{array}{c}2,8,9,10,11 \\
13,22\end{array}$ & 78,15 & Tercapai \\
\hline 4 & $\begin{array}{l}\text { Menjelaskan daur biogeokimia dan tipe- tipe } \\
\text { ekosistem. }\end{array}$ & $4,6,14,15,20$ & 77,05 & Tercapai \\
\hline 5 & Mendekskripsikan peristiwa terjadinya suksesi. & $16,17,24,25$ & 83,08 & Tercapai \\
\hline
\end{tabular}

Hasil Observasi Kemampuan Berpikir Kreatif Siswa Berdasarkan hasil kemampuan berpikir kreatif siswa yang diperoleh dengan menggunakan model pembelajaran Treffinger menunjukkan skor rata-rata kemampuan berpikir kreatif siswa mencapai nilai $75,04 \%$ yang termasuk ke dalam kategori kreatif. Berikut data observasi kemampuan berpikir kreatif siswa disajikan pada Tabel 3.

Tabel 3. Distribusi Frekuensi Skor Rata-Rata Kemampuan Berpikir Kreatif Siswa

\begin{tabular}{cccc}
\hline No. & Skor & Kategori & Frekuensi \\
\hline 1 & $85 \%-100 \%$ & Sangat Kreatif & 6 \\
2 & $75 \%-84 \%$ & Kreatif & 14 \\
3 & $60 \%-74 \%$ & Cukup Kreatif & 12 \\
4 & $50 \%-59 \%$ & Kurang Kreatif & 2 \\
5 & $<50 \%$ & Sangat Kurang Kreatif & 0 \\
\hline
\end{tabular}

Berdasarkan data kemapuan berpikir kreatif di atas, diperoleh bahwa tidak ada siswa yang tergolong sangat kurang kreatif. Adapun ringkasan persentase setiap indikator kemampuan berpikir kreatif tersaji pada Tabel 4.

Tabel 4. Persentase Indikator Kemampuan Berpikir Kreatif

\begin{tabular}{ccccccc}
\hline No & Indikator KBK & KBK 1 & KBK 2 & KBK 3 & KBK4 & Rata-Rata \\
\hline 1 & B. Lancar & 90,44 & 86,76 & 79,41 & 82,35 & $84,74 \%$ \\
2 & B. Luwes & 78,67 & 75 & 62,5 & 91,91 & $77,02 \%$ \\
3 & B. Orisinil & 80,14 & 70,58 & 86,76 & 91,91 & $82,34 \%$ \\
4 & B. Elaboratif & 43,38 & 41,17 & 60,29 & 65,44 & $52,57 \%$ \\
5 & B. Evaluatif & 55,88 & 72,05 & 79,41 & 76,47 & $70,95 \%$ \\
\hline
\end{tabular}

Keterangan : KBK=Kemampuan Berpikir Kreatif

Dari lima indikator kemampuan berpikir kreatif siswa yang diamati oleh observer, diperoleh $80 \%$ sudah tergolong kreatif, dan 20\% tergolong kurang kreatif. Indikator kemampuan berpikir kreatif yang tergolong 
kreatif (80\%) yaitu: kemampuan berpikir lancar, berpikir luwes, berpikir orisinil, dan berpikir evaluatif, yang tergolong kurang kreatif (20\%) yaitu kemampuan berpikir elaboratif dan tidak ada siswa yang tergolong tidak kreatif.

\section{PEMBAHASAN}

\section{Hasil Belajar}

Berdasarkan analisis data hasil penelitian, diperoleh bahwa model pembelajaran Treffinger efektif digunakan untuk pembelajaran biologi terkhusus pada materi ekologi. Hal tersebut terbukti dari adanya peningkatan hasil belajar yang signifikan dimana nilai post-test lebih tinggi daripada nilai pretest, sehingga dapat dikatakan bahwa tujuan mengajar telah tercapai.

Hal ini sesuai dengan penelitian yang dilakukan oleh Muhaiminu (2014) yang menyatakan bahwa Model pembelajan Treffinger berbantuan lembar kerja siswa efektif terhadap hasil belajar siswa kelas XI IPA pada materi kelarutan dan hasil kali kelarutan. Yunus (2018) juga membuktikan bahwa penerapan model pembelajaran Treffinger dapat meningkatkan hasil belajar siswa kelas VIII ${ }^{1}$ SMP Negeri 6 kota Ternate pada konsep usaha dan energy.

Berdasarkan penelitian di atas, maka peneliti menyimpulkan bahwa penggunaan model Treffinger efektif digunakan dalam pembelajaran karena dapat meningkatkan pemahaman konsep hasil belajar siswa.

Dari data yang sudah dipaparkan pada sub bab sebelumnya juga menunjukkan bahwa model pembelajaran Treffinger efektif dalam meningkatkan penguasaan siswa terhadap materi yang diajarkan, meskipun tidak seluruhnya siswa memperoleh tingkat penguasaan dengan kategori sangat tinggi. Hal ini sejalan dengan Sabri (2005) yang menunjukkan bahwa hanya sebagian kecil siswa mampu menguasai bahan hingga 90\% $-100 \%$ dari pengajaran guru. Sebagian besar siswa hanya mampu menguasai antara $50 \%$ - $80 \%$ bahkan ada yang lebih kecil. Adanya variasi penguasaan ini mencerminkan adanya variasi kemampuan siswa.

Untuk ketuntasan belajar siswa, diperoleh bahwa ketuntasan belajar secara klasikal telah terpenuhi karena lebih dari $85 \%$ siswa dinyatakan telah tuntas belajar berdasarkan pencapaian nilai tes $\geq 75$. Hasil ini menunjukkan bahwa penggunaan model pembelajaran Treffinger efektif dalam meningkatkan hasil belajar siswa.

Sementara untuk ketercapaian indikator diketahui bahwa semua indikator telah tercapai. Menurut Sanjaya (2006) keberhasilan pembelajaran itu diukur dari sejauh mana siswa dapat menguasai atau mencapai tujuan khusus. Pencapaian tujuan belajar atau pencapaian kompetensi dapat dilihat dari keberhasilan siswa dan ketercapaian indikator. Hasil penelitian yang telah dilakukan memperlihatkan bahwa dengan menggunakan model pembelajaran Treffinger, siswa dapat mencapai ketuntasan indikator. Hal ini menunjukkan adanya keberhasilan pembelajaran dengan menggunakan model pembelajaran Treffinger, yang terlihat bahwa ketercapaian indikator secara keseluruhan telah terpenuhi dari batas minimum $75 \%$.

Dengan model pembelajaran Treffinger ini, siswa dapat memahami konsep-konsep yang dipelajarinya dari permasalahan yang diberikan sesuai dengan materi pelajaran yang sedang dipelajari dan diakhiri dengan melakukan evaluasi dalam bentuk post-test sehingga dapat menjadi umpan balik untuk tercapainya indikator pembelajaran.

Tolak ukur keberhasilan penggunaan suatu model mengajar yang digunakan dalam mengajarkan suatu materi pada penelitian ini terdiri dari tiga hal yaitu: 1) Tingkat Penguasaan Siswa, 2) Ketuntasan Belajar, 3) Ketercapaian Indikator. Dari hasil penelitian dan pengolahan data yang dilakukan diketahui bahwa penggunaan model pembelajaran Treffinger yang digunakan untuk mengajarkan materi ekologi di kelas X MIA SMA Swasta Dharma Pancasila Medan Tahun Pembelajaran 2017/2018 dinyatakan telah berhasil.

Keberhasilan pembelajaran yang telah dicapai dalam penelitian ini terjadi karena beberapa faktor. Salah satu diantaranya adalah keunggulan model pembelajaran Treffinger yang meliputi: 1) memberi kesempatan kepada siswa untuk memahami konsep-konsep dengan cara menyelesaikan suatu permasalahan; 2) membuat siswa aktif dalam pembelajaran; 3) mengembangkan kemampuan berpikir siswa karena disajikan masalah pada awal pembelajaran dan memberi keleluasaan kepada siswa untuk mencari arah-arah penyelesaiannya sendiri; 4) mengembangkan kemampuan siswa untuk mendefenisikan masalah, mengumpulkan data, menganalisis data, membangun hipotesis, dan percobaan untuk memecahkan suatu permasalahan; dan 5) membuat siswa dapat menerapkan pengetahuan yang sudah dimilikinya ke dalam situasi baru.

\section{Hasil Observasi Kemampuan Berpikir Kreatif}

Hasil observasi kemampuan berpikir kreatif yang telah dipaparkan menunjukkan bahwa model pembelajaran Treffinger dapat meningkatkan kemampuan berpikir kreatif siswa dibandingkan dengan observasi langsung yang dilakukan peneliti sebelum melakukan penelitian. 
Hal ini sejalan dengan penelitian Akbar (2015) “Efektivitas Model Pembelajaran Treffinger untuk Meningkatkan Kemampuan Berpikir Kreatif Siswa" yang menunjukkan bahwa kelompok siswa yang mendapat perlakuan dengan model pembelajaran Treffinger pada mata pelajaran ekonomi mempunyai peningkatan kemampuan berpikir kreatif yang signifikan dibandingkan dengan kelompok siswa yang tidak mendapat perlakuan.

Nisa (2011) juga membuktikan bahwa model pembelajaran kooperatif tipe Treffinger dapat membantu siswa untuk berpikir kreatif dalam memecahkan masalah, membantu siswa dalam menguasai konsep - konsep materi yang diajarkan, serta memberikan kesempatan kepada siswa untuk menunjukkan potensi-potensi kemampuan yang dimilikinya termasuk kemampuan kreativitas dan kemampuan pemecahan masalah untuk diimplementasikan secara nyata, serta memberikan saran-saran praktis bagaimana mencapai keterpaduan. Keterpaduan yang dimaksud adalah melibatkan unsur kognitif dan afektif sehingga hasil belajar peserta didik meningkat.

Berdasarkan data kemampuan berpikir kreatif yang sudah dipaparkan pada sub bab sebelumnya, diperoleh kemampuan berpikir lancar dengan persentase yang lebih tinggi dibanding indikator lainnya. Hal ini diakibatkan karena hampir keseluruhan dari sintaks model Treffinger ini lebih sering melatihkan kemampuan berpikir lancar daripada kemampuan lainnya. Dimana fluency (kelancaran) yaitu kemampuan untuk memunculkan banyak ide, cara, saran, pertanyaan, gagasan atau alternatif jawaban dengan lancar dalam waktu tertentu secara cepat yang ditekankan pada kualitas jawaban. Kemudian persentase kedua setelah kemampuan berpikir lancar yaitu kemampuan berpikir orisinil, diikuti dengan kemampuan berpikir luwes dengan persentase yang tidak jauh berbeda dari indikator berpikir lancar. Sedangkan indikator kemampuan berpikir yang paling rendah yaitu kemampuan berpikir elaboratif. Hal ini disebabkan karena kemampuan elaboratif termasuk dalam kemampuan berpikir kreatif tingkat tinggi dimana siswa dituntut mampu untuk mengembangkan suatu produk atau gagasan, dan menambah atau memperinci detail-detail dari suatu objek sehingga sebagian siswa mengalami kesulitan. Penelitian yang dilakukan oleh Mufiannoor (2016) juga memberikan argumennya bahwa penyebab lainnya yaitu siswa terbiasa dengan pembelajaran konvensional yang hanya memberikan sedikit kesempatan kepada siswa untuk dapat mengemukakan banyak gagasan atau ide.

Dari lima indikator kemampuan berpikir kreatif siswa yang diamati oleh observer, tidak ada siswa yang tergolong tidak kreatif. Hal ini sesuai dengan pendapat dari Ruseffendi dalam Sunaryo, Y.,(2014) menyatakan bahwa setiap siswa memiliki potensi kritis dan kreatif, tetapi masalahnya bagaimana cara mengembangkan potensi tersebut melalui proses pembelajaran di kelas. Sifat kreatif akan tumbuh dalam diri anak bila ia dilatih, dibiasakan sejak kecil untuk melakukan eksplorasi, inkuiri, penemuan dan memecahkan masalah.

Berdasarkan penjelasan di atas, maka model pembelajaran Treffinger merupakan salah satu model yang dapat digunakan untuk memberikan hasil yang baik terhadap hasil belajar. Hal ini sesuai dengan Muliyani (2017) yang menyatakan bahwa, pembelajaran dengan model Treffinger memberikan pengaruh positif terhadap hasil belajar baik kognitif maupun afektif. Hal ini seperti yang dijelaskan Munandar (2000) bahwa dalam pembelajaran model Treffinger ranah kognitif dikembangkan pada setiap tingkat atau langkah model Treffinger tersebut, dan dapat mengembangkan aspek afektif siswa.

\section{Efektivitas Model Pembelajaran Treffinger}

Dari hasil penelitian ini, diketahui bahwa model pembelajaran Treffinger efektif digunakan pada pembelajaran biologi khususnya pada materi ekologi di kelas X MIA SMA karena model pembelajaran ini memberikan pengaruh dalam peningkatan hasil belajar siswa. Hal ini diketahui dari hasil pengolahan data, dimana terdapat 31 siswa atau 91,18\% dari keseluruhan siswa dinyatakan telah lulus dalam belajar karena telah memperoleh persentase tingkat penguasaan antara 75 - 100. Sedangkan secara klasikal (kelompok), dinyatakan telah tuntas dalam belajar karena hanya 3 siswa yang tidak tuntas dalam belajar. Hal ini sejalan dengan yang diutarakan oleh Arifin (2009), apabila siswa memperoleh nilai post-test $\geq 75$ maka tingkat penguasaan siswa tersebut sudah termasuk kategori sedang, dan menurut Suryosubroto (2002) siswa tuntas belajar apabila siswa tersebut telah mencapai skor 75 dan kelas dinyatakan tuntas dalam belajar apabila di dalam kelas tersebut terdapat $\geq 85 \%$ siswa yang telah tuntas belajarnya. Selain itu juga mempengaruhi peningkatan kemampuan berpikir kreatif siswa di dalam kelas pada saat proses belajar mengajar sedang berlangsung. Adapun ringkasan pencapaian efektivitas model pembelajaran Treffinger dapat di lihat pada Tabel 5. 
Tabel 5. Pencapaian Efektivitas Model Treffinger

\begin{tabular}{clcl}
\hline No. & \multicolumn{1}{c}{ Kriteria } & Keterangan & Kesimpulan \\
\hline 1 & Tingkat penguasaan siswa & Terpenuhi & \\
2 & Ketuntasan belajar siswa & Tuntas & Efektif \\
3 & Ketercapaian Indikator & Tercapai & \\
\hline
\end{tabular}

\section{KESIMPULAN}

Pembelajaran biologi dengan menggunakan model pembelajaran Treffinger efektif digunakan pada materi Ekologi dilihat dari tingkat penguasaan siswa mencapai 80,47 termasuk kategori tinggi, ketuntasan belajar siswa mencapai 91,18\% termasuk kategori tuntas, ketercapaian indikator mencapai $81 \%$ termasuk kategori tercapai, dan kemampuan berpikir kreatif siswa yang mencapai $75,04 \%$ termasuk ke dalam kategori kreatif.

\section{DAFTAR PUSTAKA}

Akbar, P., Syaodih, E.,Lisnawati, C., (2015), Efektivitas Model Pembelajaran Treffinger untuk Meningkatkan Kemampuan Berpikir Kreatif Siswa, Jurnal Pendidikan dan Pembelajaran Ekonomi Akutansi, Vol. 1, No.1, hal. 33-46.

Arifin, Z., (2009), Evaluasi Pembelajaran, Remaja Rosdakarya, Bandung.

Hasruddin, Harahap, Fauziyah, Mahmud, (2018), Efektivitas Penerapan Perangkat Perkuliahan Mikrobiologi Berbasis Kontekstual Terhadap Kemampuan Berpikir Tingkat Tinggi Mahasiswa Pendidikan Biologi Unimed, Jurnal Pendidikan Biologi, Vol. 11, No.1, hal. 51-54, ISSN; 1693-265X.

Munandar, U., (2000), Pengembangan Kreativitas Anak Berbakat, Gramedia Pustaka, Jakarta.

Mufiannoor, E., Hidayat, T., Soetjipto, (2016), Melatihkan Kemampuan Berpikir Kreatif Dan Pemahaman Konsep Dengan Pembelajaran Berbasis Inkuiri Terbimbing Pada Materi Interaksi Makhluk Hidup Dengan Lingkungannya, Jurnal Pendidikan Sains Pascasarjana, Vol. 5, No. 2, ISSN: 2089 - 1776.

Muhaiminu, (2014), Efektivitas Model Pembelajaran Treffinger Berbantuan Lembar Kerja Siswa Terhadap Hasil Belajar Siswa SMA, Skripsi, FMIPA, Universitas Negeri Semarang.

Muliyani, Leny, Suharto, (2017), Pengaruh Model Pembelajaran Treffinger Terhadap Kemampuan Berpikir Kreatif dan Hasil Belajar Hidrolisis Garam SiswaKelas XI IPA SMA Negeri
5 Banjarmasin Tahun Pelajaran 2016/2017, Journal ofChemistry and Education, Vol. 1, No.1, hal; 86-92.

Nisa, T., (2011), Pembelajaran Matematika dengan Setting Model Treffinger untuk Mengembangkan Kreativitas Siswa, Pedagogia, Vol. 1, No. 1, hal. 35-30.

Sari, Y. dan Putra, (2015), Pengaruh Model Pembelajaran Treffinger Terhadap Kemampuan Berpikir Kritis Dan Kreatif Mahasiswa Universitas Kanjuruhan Malang, Jurnal Pendidikan Geografi, No.2.

Sabri, A., (2005), Strategi Belajar Mengajar Microteaching, Penerbit Quantum Teaching, Jakarta.

Sanjaya, W., (2006), Strategi Pembelajaran Berorientasi Standar Proses Pendidikani, Penerbit Prenada Media Group, Jakarta.

Sunaryo, Y., (2014), Model Pembelajaran Berbasis Masalah untuk Meningkatkan Kemampuan Berpikir Kritis dan Kreatif Matematik Siswa SMA di Kota Tasikmalaya, Jurnal Pendidikan dan Keguruan, Vol. 1, No. 2.

Suryosubroto, B., (2002), Proses Belajar Mengajar di Sekolah, Rineka Cipta, Jakarta.

Trianto, (2011), Mendesain Model Pembelajaran Inovatif - Progresif, Kencana Prenada Media Group, Jakarta.

Wirahayu, Y., Purwito, H., Juarti, (2017), Penerapan Model Pembelajaran Treffinger dan Keterampilan Berpikir Divergen Mahasiswa, Journal Pendidikan Geografi, No.1, Hal. 30.40, ISSN: 0853-9251.

Yunus, M., (2018), Penerapan Model Pembelajaran Treffinger untuk Meningkatkan Hasil Belajar Siswa Kelas VIII ${ }^{1}$ SMP Negeri 6 Kota Ternate, Jurnal Hibualamo, Vol. 2, No. 1, ISSN: 25497030. 